\title{
LAND USE CHANGE IN BUFFER ZONE OF CHITWAN NATIONAL PARK, NEPAL BETWEEN 1978 AND 1999
}

\author{
N.G. Baidya, D.R. Bhuju ${ }^{*}$ and P. Kandel ${ }^{* *}$ \\ Wildlife Conservation Nepal, Bafal, Kathmandu \\ *Nepal Academy of Science and Technology, Khumaltar, Lalitpur \\ ${ }^{* *}$ Ministry of Forests and Soil Conservation, Singh Durbar, Kathmandu
}

\begin{abstract}
Land use dynamics in the Buffer Zone of Chitwan National Park was assessed by integrated use of Remote Sensing and Geographic Information System covering 1978, 1992 and 1999. Among all landuse type, forest was the most dominating land-use in 1978 covering $45.33 \%$ of total study area. However, the agricultural land became the most dominating land-use since 1992. The study found that since 1978 to 1999 there was increase in agricultural land by $67.28 \mathrm{~km}^{2}$, built-up area by 0.81 $\mathrm{km}^{2}$ and shrub-land by $7.68 \mathrm{~km}^{2}$. Whereas, the forest decreased by $62.23 \mathrm{~km}^{2}$, grassland by $11.38 \mathrm{~km}^{2}$ and water bodies by $2.16 \mathrm{~km}^{2}$. Vegetation density analysis using Normalized Difference Vegetation Index (NDVI) revealed that the densely vegetated area decreased by $5.03 \mathrm{~km}^{2}$ in a time-span of less than 10 years. Despite the successful community forest management in the BZ of CNP, this study showed a decline in densely forested area.
\end{abstract}

Key words: GIS, Land use types, management, Remote sensing, Vegetation.

\section{INTRODUCTION}

Reliable data on land use dynamics are essential for proper management, planning and sustained utilization of the natural resources. The study of land use and land cover provides information about the status of natural resources and is helpful in monitoring, modeling and environmental change detection (Krishna et al., 2001). Remote Sensing (RS) and Geographic Information System (GIS) technology have emerged as important tools in recent time for monitoring and management of natural resources including conservation areas. The conventional methods of detecting change in natural resources are costly and low in accuracy. With the help of the fusion of both conventional and RS techniques, monitoring of land-use changes can be done accurately and effectively (Reddy and Bhattacahrya 1995, Carver et al. 1995, Rahman et al. 1995, Skidmore et al. 1997).

All land-based resources are dynamic in nature, which is enhanced by human intervention. Human changes existing land use patterns to their requirement, for instance, forests into agriculture and/or settlements. One pertaining issue of land use pattern in Nepal is to determine the major cause of forest fragmentation. Chitwan National Park (CNP), a world heritage site and popular tourist destination, has been contributing to national economy besides protecting endangered species. A buffer zone (BZ) surrounding the national park was created to cushion park from 
negative impacts of human activities in 1996. Human activities are restricted in the park; however, the BZ has faced continued changes in landuse pattern due to residing human population which has ultimately posed threat to the National Park.

The present study was carried out with an objective to develop an understanding on the utilization of RS and GIS in detecting the change on land-use pattern and change on vegetation index in the CNP-BZ. The specific objectives were: to create GIS database of the landuse type of the study area, to study the trend of land-use change on the natural environ, and to compare the situation of the study area before and after the declaration of Buffer Zone.

\section{METHODS}

\section{Study Area}

Chitwan National Park (location: $27^{\circ} 16^{\prime} 56^{\prime \prime}-$

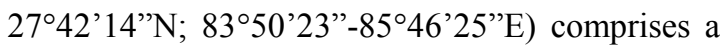
complex ecosystem of Churiya hills, ox-bow lakes and flood plains of Rapti, Reu and Narayani rivers (Fig. 1). It has tropical monsoon type of climate with relatively high humidity. Mean annual rainfall ranges between $2000-2100 \mathrm{~mm}$ with $>80 \%$ of the total rainfall occurring in four months (JuneSeptember). Annual average minimum air temperature was recorded to be $17.4^{\circ} \mathrm{C}$ with the annual average daily air temperature of $24.1^{\circ} \mathrm{C}$ (DHM 1995). May is usually the hottest month with air temperature up to $39.1^{\circ} \mathrm{C}$. The park is dominated by Sal (Shorea robusta) forest, and also contains Sal-pine forest, riverine forest and grass land. The GPS survey of the BZ boundary and the GIS digitization based on 1992 topo-maps show a total area of $767 \mathrm{~km}^{2}$ (DNPWC 2000). Nearly 300,000 people are residing in 35 Village Development Committees and two municipalities in the BZ. Crop raiding, livestock depredation and loss of lives are associated with the spill-over of growing populations of large mammals from the parks into adjacent areas creating opportunity for ecotourism development and dilemma for park management.

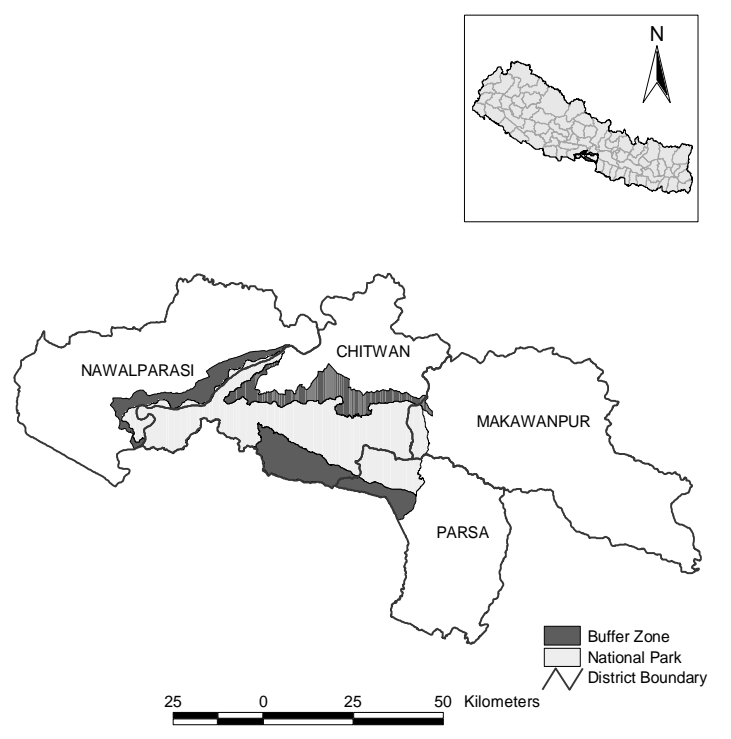

Fig. 1. Location of Chitwan National Park and Buffer Zone.

\section{Data Sources and Analysis}

The present study used three softwares: (1) Ilwis 3.1 (vendor ITC) for image processing and accuracy analysis, (2) PC ArcInfo 3.5.2 and ArcView 3.2 (vendor ESRI) for digitization and analysis, and (3) MS Excel for data entering. The major data sources were as follows:

1. Land utilization map (total 7 sheets) of $1978 / 79$ at the scale of 1:50,000 prepared Land Resources Mapping Project (LRMP) by Kenting Earth Sciences, Canada, and Department of Survey, Nepal, for land use pattern of 1978 .

2. Topographic maps (total 20 sheets) of 1992 , scale of 1:25,000 (FINMAP), produced by FINNIDA and Department of Topographical Survey (DOTS), Nepal based on aerial photograph, for land use pattern of 1990 . 
3. Satellite image (LANSAT TM) of spatial resolution $30 \mathrm{~m} \times 30 \mathrm{~m}$ in digital format (Jan 1999, path=142 and Row=41) provided by Department of Forest Research and Survey (DOFRS), Nepal, for land use pattern of 1992.

4. Boundary map of CNP and its BZ in digital format provided by Department of National Park and Wildlife Conservation (DNPWC), Nepal.

For digitization of maps PC ArcInfo 3.5.2 (ESRI) software and Altek AC30 digitizing board were used. The RMS Error up to 0.005 was accepted to get precise information while digitizing. Field-visit was conducted in September 2004 and October 2005 mainly in the Sauraha and Kasara area of CNP-BZ. GPS was used to collect such data. Once all the map layers were prepared, they were projected and transformed into the Transverse Mercator system using Universe Transverse Mercator (UTM) zone 45 projection system. Since the study was mainly based upon the map data, several data layers were generated from the base map.

The raw image (LANSAT TM) provided by DOFRS was first geo-referenced using sufficient identifiable Ground Controls Points obtained from 1:25000 scale topographic map (FINIDA map) as it was essential that both datasets be correctly spatially referenced to one another so that overlay analysis could be performed. Mainly cross-sections of roads that were identified on the satellite image had been used for geo-referencing the image. Same GCPs were used to geo-reference satellite image of 1999. Universal transverse Mercarator (UTM) projection system, zone 45 with spheroid everest 1830 was used as the referencing scheme.

In this study sigma (root mean square error) of \pm 0.5 pixels i.e., $15 \mathrm{~m}$ on the ground was accepted. After geo-referencing image, mosaics were created by using map glue command. Using the boundary map obtained from DNPWC, sub-map of study area was created. Thus, obtained geo-coded Lansat TM image of study area was viewed in different color composites for visual interpretation. For classification operation, Maximum Likelihood Classifier (MLC) algorithm was adopted using the training samples obtained from the collection of sample data as well as visual inspection of color composites. Once the landuse was classified, the majority filter was used to remove unnecessary small patches from classified image. Accuracy analysis of classified imagery has been done by using the field data obtained by using GPS during field visit.

One of the most known RS methods used to determine the vegetation index is NDVI (Normalized Difference Vegetation Index). It is based on the spectral properties of green vegetation contrasting with its soil background. NDVI is a measure derived by dividing the difference between near-infrared (NIT) and red (R) reflectance measurements by their sum:

$$
\mathrm{NDVI}=(\mathrm{NIR}-\mathrm{R}) /(\mathrm{NIR}+\mathrm{R})
$$

Observing the histogram, the NDVI values were density sliced to delineate into four classes namely no-vegetation, low vegetation, medium vegetation and dense vegetation and then color coded. Thus obtained vegetation map were compared and analyzed.

\section{RESULTS AND DISCUSSION}

\section{Land-use pattern 1978}

Four main categories of land-use were seen in this period. The land-use patterns included agricultural land, forest, grassland, and waterbodies (Table 1). Agriculture land covered 347.01 $\mathrm{km}^{2}$ which was $45.24 \%$ of the total area. Forest covered $347.65 \mathrm{~km}^{2}$ (45.33\%) which was the largest area coverage among the different land-use types. Similarly, grassland covered $26.97 \mathrm{~km}^{2}$ 
(3.52\% of total area) and water bodies covered $45.36 \mathrm{~km}^{2}(5.91 \%$ of total area).

\section{Land-use pattern 1992}

Six main categories of landuse were seen in the study area. The land-use pattern included agriculture land, built-up area, forest, grassland, shrub land and water-bodies (Table 1). In this period, agricultural land dominated the other landuse types covering $362.84 \mathrm{~km}^{2}$ (47.31\% of total area). Forest occupied $308.25 \mathrm{~km}^{2}$ (40.19\%) whereas grassland and shrub-land occupied 15.41 $\mathrm{km}^{2}(2.01 \%)$ and $18.42 \mathrm{~km}^{2}(2.40 \%)$ respectively. Built-up area occupied the least area $0.80 \mathrm{~km}^{2}$ $(0.10 \%)$ among the land-use types present.

\section{Land-use pattern 1999}

Six main types of land-use classes were obtained after image classification process (Table 1). The land-use pattern includes agriculture land, built-up area, forest, grassland, shrub land and water-bodies. In 1999, agriculture land was found to be the dominating landuse type covering an area of $414.30 \mathrm{~km}^{2}(54.01 \%)$ and was followed by forest which occupied $285.43 \mathrm{~km}^{2}(37.21 \%)$ then water-bodies occupying $43.20 \mathrm{~km}^{2} \quad(5.63 \%)$. Grassland and shrub-land occupied $15.60 \mathrm{~km}^{2}$ $(2.03 \%)$ and $7.68 \mathrm{~km}^{2}(1.00 \%)$ respectively, whereas the built-up area occupied the least area of $0.80 \mathrm{~km}^{2}(0.10 \%)$.

Table 1. Land-use pattern of Buffer Zone in Chitwan National Park in 1978, 1992 and 1999.

\begin{tabular}{lccc}
\hline & \multicolumn{3}{c}{ Area in sq. km. } \\
Land-use type & $\mathbf{1 9 7 8}$ & $\mathbf{1 9 9 2}$ & $\mathbf{1 9 9 9}$ \\
\hline Agriculture land & 347.01 & 362.84 & 414.30 \\
Built-up Area & & 0.80 & 0.80 \\
Forest & 347.65 & 308.25 & 285.43 \\
Grassland & 26.97 & 15.41 & 15.59 \\
Shrub land & & 18.42 & 7.68 \\
Water-bodies & 45.36 & 61.28 & 43.20 \\
Grand Total & 767.00 & 767.00 & 767.00 \\
\hline
\end{tabular}

\section{Accuracy of the classification}

Confusion matrix obtained from this accuracy assessment is shown in Table 2. Although the overall accuracy of this classification is $79.01 \%$, the commission error of forest is very low i.e., $2.27 \%$ and commission error of shrub-land is high i.e., $52.85 \%$. Similarly, the omission error of forest is comparatively low $8.51 \%$ whereas that of waterbodies is $32.43 \%$. Since ground data was collected in September 2004 accuracy classification is only done for 1999 land use classification.

Table 2. Classification error matrix of land-use classification of 1999

\begin{tabular}{|c|c|c|c|c|c|c|c|c|}
\hline \multirow{8}{*}{ 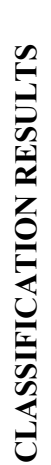 } & \multicolumn{8}{|c|}{ GROUND TRUTH } \\
\hline & & $\begin{array}{l}\text { Agricultural } \\
\text { land }\end{array}$ & Forest & $\begin{array}{l}\text { Grass } \\
\text { Land }\end{array}$ & $\begin{array}{l}\text { Shrub } \\
\text { Land }\end{array}$ & $\begin{array}{l}\text { Water } \\
\text { bodies }\end{array}$ & Total & $\begin{array}{c}\text { Commission } \\
\text { Error }\end{array}$ \\
\hline & Agr. land & 65 & 1 & 0 & 1 & 3 & 70 & $7.14 \%$ \\
\hline & Forest & 0 & 43 & 1 & 0 & 0 & 44 & $2.27 \%$ \\
\hline & Grass Land & 5 & 0 & 31 & 2 & 5 & 43 & $27.90 \%$ \\
\hline & Shrub Land & 6 & 2 & 2 & 13 & 4 & 27 & $51.85 \%$ \\
\hline & Water bodies & 12 & 1 & 1 & 1 & 25 & 40 & $37.50 \%$ \\
\hline & Total & 88 & 47 & 35 & 17 & 37 & 224 & \\
\hline & Omission Error & $26.13 \%$ & $8.51 \%$ & $11.42 \%$ & $23.52 \%$ & $32.43 \%$ & & $79.01 \% *$ \\
\hline
\end{tabular}

*overall accuracy 
Table 3. Gain/Loss in land-use in Buffer Zone of Chitwan National Park 1978-1999.

\begin{tabular}{lccc}
\hline Landuse Type & $\begin{array}{c}\text { Gross } \\
\text { Gain } \\
\text { in } \mathbf{~ k m}^{2}\end{array}$ & $\begin{array}{c}\text { Gross } \\
\text { Loss } \\
\text { in } \mathbf{~ k m}^{2}\end{array}$ & $\begin{array}{c}\text { Net Change } \\
\text { in } \mathbf{~ k m}^{2}\end{array}$ \\
\hline Agriculture Land & 97.4081 & 30.1252 & 67.2829 \\
Built-up area & 0.8055 & & 0.8055 \\
Forest & 7.8542 & 70.0738 & -62.2195 \\
Grass Land & 15.0223 & 26.4063 & -11.3839 \\
Shrub Land & 7.6772 & & 7.6772 \\
Water-bodies & 22.1727 & 24.3348 & -2.1622 \\
\hline
\end{tabular}

\section{Land-use change 1978 - 1999}

An overall land-use change that occurred from 1978 to 1999 was obtained from LRMP 1978 and LANSAT TM 1999. The results are shown in Table 3 and Fig. 2. During this period, there was net gain in area of agricultural land by $67.28 \mathrm{~km}^{2}$. About $97.41 \mathrm{~km}^{2}$ of other land-use type was converted into agricultural land whereas $30.13 \mathrm{~km}^{2}$ of agricultural land was converted into other land use type and $316.89 \mathrm{~km}^{2}$ of agricultural land remained unchanged. The agricultural land had been converted into built-up area, forest, grass land, shrub land and water-bodies by $0.81 \mathrm{~km}^{2}$, $3.12 \mathrm{~km}^{2}, 10.54 \mathrm{~km}^{2}, 2.54 \mathrm{~km}^{2}$ and $13.11 \mathrm{~km}^{2}$, respectively.

No built-up area was indicated in LRMP map of 1978 whereas $0.81 \mathrm{~km}^{2}$ of built-up area was observed in the satellite imagery of 1999 indicating the net increase in built-up area by $0.81 \mathrm{~km}^{2}$ on the expense of 0.81 of agricultural land and 0.0001 $\mathrm{km}^{2}$ of grassland. From 1978 to 1999 there has been decline in the area of forest by $62.22 \mathrm{~km}^{2}$. About $7.85 \mathrm{~km}^{2}$ of other land use type has converted into forest whereas $70.07 \mathrm{~km}^{2}$ of forest has converted into other land use type and 277.58 $\mathrm{km}^{2}$ of forest has remained unchanged during this period of time. The forest has converted into agricultural land, grass land, shrub land and waterbodies by $59.210 \mathrm{~km}^{2}, 3.1075 \mathrm{~km}^{2}, 1.49 \mathrm{~km}^{2}$ and $6.26 \mathrm{~km}^{2}$, respectively.
During this period, there was decline in grassland by $11.38 \mathrm{~km}^{2}$. Though $15.02 \mathrm{~km}^{2}$ of other land-use type was converted into grass-land, 26.41 $\mathrm{km}^{2}$ of grass-land was converted into other land use type and $0.57 \mathrm{~km}^{2}$ of remained unchanged. This result indicated that grass land was the most dynamic land use type in the study area. There was increase in the area of shrub-land by $7.68 \mathrm{~km}^{2}$, which was in expense of other landuse types as shrub-land was not mentioned in the LRMP map 1978.

The water-bodies declined by $2.16 \mathrm{~km}^{2}$, while about $22.17 \mathrm{~km}^{2}$ of other land use type was converted into water-bodies and $24.33 \mathrm{~km}^{2}$ of water-bodies was converted into other land use type and $21.03 \mathrm{~km}^{2}$ of water-bodies has remained unchanged during this period of time. The waterbodies have converted into agricultural land, forest, grass land and shrub-land by $18.16 \mathrm{~km}^{2}$, $2.64 \mathrm{~km}^{2}, 1.37 \mathrm{~km}^{2}$ and $2.17 \mathrm{~km}^{2}$, respectively.

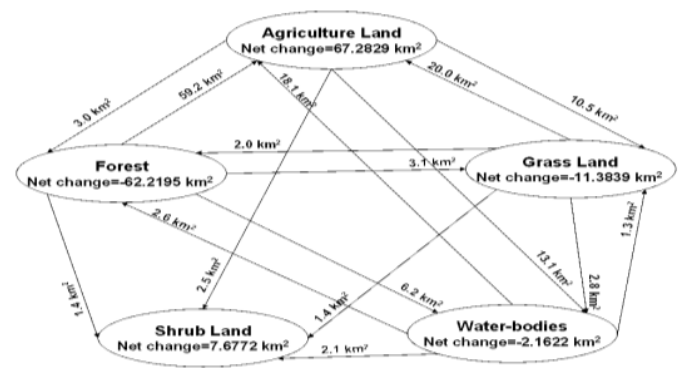

Fig. 2. Land-use change in Buffer Zone of Chitwan National Park 1978-1990.

From their study in Churiya hills of Nepal Himalaya, Bhuju et al. (2007) reported increment of agricultural land by over two-folds at the expense of forest cover, where the forest cover decreased at least by $25 \%$. They noted nearly 400 villages or human settlements in a total study area of about $780 \mathrm{~km}^{2}$. Similarly, Balla et al. (2003) reported decline in forested area in their study in two sub-watersheds namely Kali Khola and Andheri 


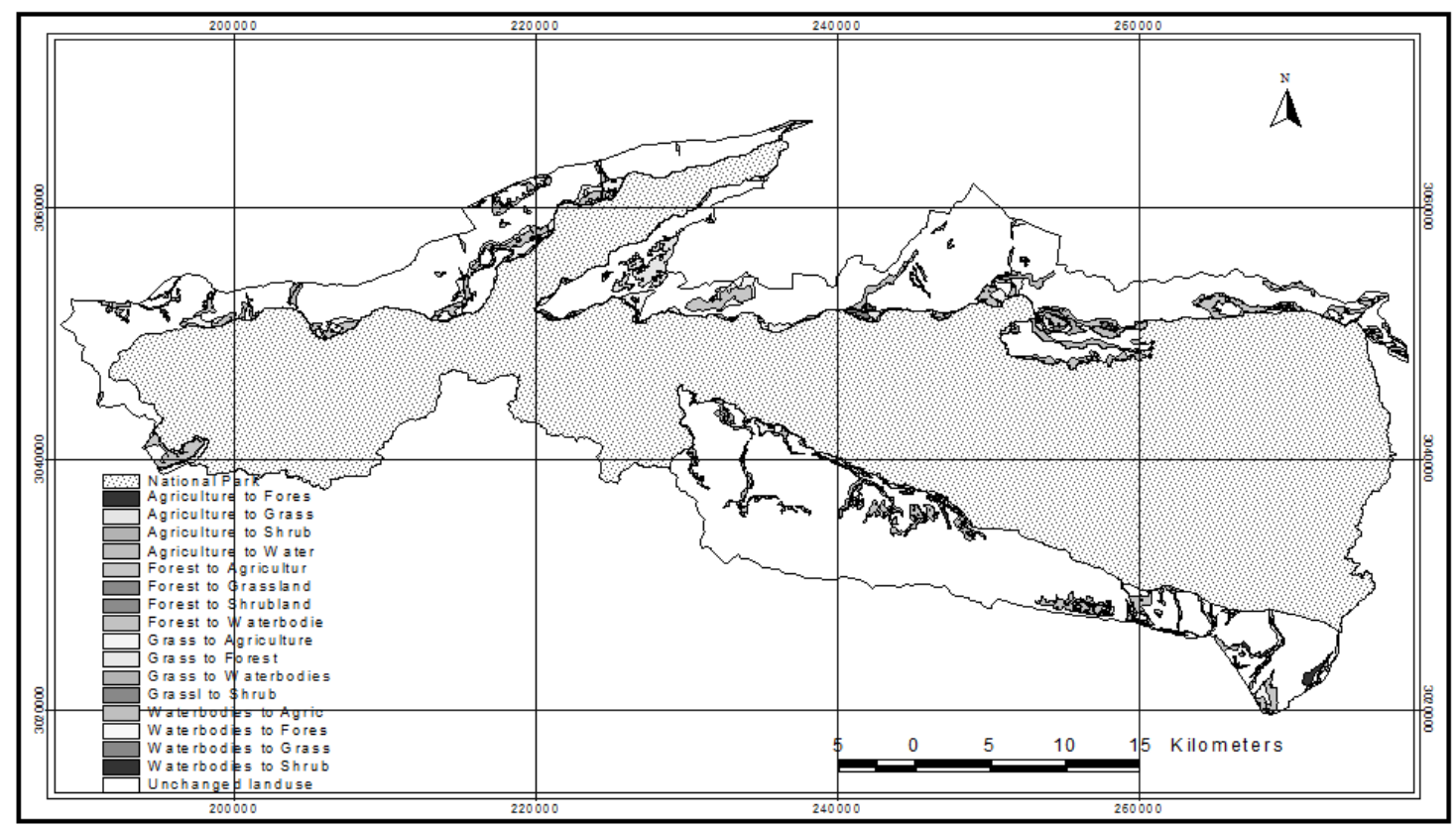

Fig. 3. Land-use change in Buffer Zone of Chitwan National Park 1978-1999.

Andheri Khahare of Chitwan and Tanahun districts using aerial photographs taken in 1978 and 1994 and land-utilization map and base maps of 1986. In Kali Khola watershed, agriculture and forest occupied 366.45 ha and 436.96 ha in 1999 whereas it was 194.90 ha and 537.36 ha in 1978 respectively. The increase in agriculture area came from forest, shrub-land and shifting cultivation with $32.81 \%$ of forestland converted into shifting cultivation and agriculture.

In a paper by Pariyar and Singh (1995) a methodology for detecting land-use changes using remote sensing techniques and GIS has been demonstrated. Chitwan district of Nepal was selected for their case study. Analogue maps of 1978/79 on the land utilization, LANSAT TM-5 images of 1990 and aerial photographs of $1992 \mathrm{had}$ been used and five different land-use types viz. cultivated land, forest land, grazing land, urban land and river bed, were delineated. Their study showed that the agricultural land area in the district had shrunk by about $11 \%$ during the period 1978 to 1992 . The total area under forest and grazing had remained nearly unchanged. The urban land area in 1992 was almost twice that in 1978; and the area under river bed has increased.

Sotomayor (2002) tested whether the LANSAT-TM data was suitable to assess the species richness, stem density and basal area of three forest strata in the Shivapuri area. The study used vegetation database and the models of spatial distribution patterns of tree species developed by Acharya in 1999 (cited in Sotomayor 2002). The results showed no correlation between pure radiance data and vegetation data but the modeling with Forest Canopy Density Map program showed very good capacity to bring information about the actual forest cover. It was recommended that the use of remotely sensed images for the future monitoring of the forest cover type in the area as it allows faster studies and monitoring the forest cover and their spatial characteristics. 
The vegetation density analysis using NDV index had also revealed decrease in densely vegetated area by $5.03 \mathrm{~km}^{2}$ between 1990 and 1999. Despite the successful community forest management in the BZ of CNP like Bagmara, Mrigakunj, Kumroj etc this study shows decline in forested area as well as decline in densely vegetated area. Thus, BZ managers should review their BZ management plans and new policies should be developed in order to cope with this problem.

\section{CONCLUSION}

Land-use in the BZ of CNP is dynamic. From 1978 to 1999, there has been increase in agricultural land by $67.28 \mathrm{~km}^{2}$, built-up area by $0.8055 \mathrm{~km}^{2}$ and shrub-land by $7.678 \mathrm{~km}^{2}$. However, forest has decreased by $62.2 \mathrm{~km}^{2}$, grassland by $11.38 \mathrm{~km}^{2}$ and area of water bodies has also been decreased by $2.16 \mathrm{~km}^{2}$. Among all land-use type forest had been the most dominating land-use type in 1978 covering $45.32 \%$ of total study area. However, since 1992 the agricultural land had become the most dominating land-use type in 1999 whereas forest was the second dominating land-use type. The vegetation density analysis using NDV index revealed a decrease in densely vegetated area by $5.03 \mathrm{~km}^{2}$ between 1990 and 1999. The combination of Remote Sensing and Geographic Information System techniques used in this study was found to be effective in understanding the rate of land-use change in time and space. Thus, the technique may be useful in preparing the model for the regional spatial pattern and future prediction of implications of these changes.

\section{ACKNOWLEDGEMENTS}

Resources Himalaya Foundation provided technical supports in conducting the study. Satellite images (LANSAT TM) of 1999 were availed by Department of Forest Research and Survey and digital copy of the Chitwan National Park and its Buffer Zone by Participatory Conservation Program.

\section{REFERENCES}

Balla, M.K., K.D. Awasthi, P.K. Shrestha and D.P. Sherchan. 2003. Land-use change in two subwatersheds in Chitwan and Tanahun districts, west Nepal. Nepal Journal of Science and Technology. 5:49-56.

Bhuju, D.R., P.B. Yonzon and B.M. Baidya, B.M. 2007. Land-use pattern and its change in the eastern Churiya hills of Nepal Himalaya. Ecoprint, 14:65-71.

Carver, S., I. Heywood, S. Cornelius and D. Sear. 1995. Evaluating field based GIS for environmental characterization, modeling, and decision support. International Journal of Geographical Information System, 9(4):475486.

DHM. 1995. Climatological Records of Nepal (1971-1986). Department of Hydrology and Meteorology, Nepal.

DNPWC. 2000. Royal Chitwan National Park and Buffer Zone Management Plan 2001-2005. Department of National Park and Wildlife Conservation, Nepal.

Krishna, N.D.R., A,K. Maji, Y.V.N. Krishna Murthy and B.S.P. Rao. 2001. Remote sensing and Geographical Information System for canopy cover mapping. J. Indian Soc. Remote Sensing, 29(3): 107-113

LRMP 1986. Land Utilization Report. Land Resource Mapping Project, Keating Earth 
Science, Canada and Survey Department, Nepal.

Pariyar, M.P. and G. Singh. 1995. Detecting land use/land-cover changes using Remote Sensing and GIS in Chitwan district of Nepal. Asia Pacific Remote Sensing Journal, 7(2): 103107.

Rahman, M.A., M.A. Jabbar, M.S. Islam and D.P. Shrestha. 1995. Study of land degradation by integration and analysis of remotely sensed data in GIS: A case study of Hathazari thana in Bangladesh. Asia-Pacific Remote Sensing Journal, 7(2):109-114.

Reddy, D.S.S. and A. Bhattacharya. 1995. Use of GPS for ground truth data collection and its integration with RS and GIS: A case study with reference to the mine fire mapping in Jharia, Bihar State, India. Asia-Pacific Remote Sensing Journal, 7(2):155-158.

Skidmore, A.K., B. Witske, K. Schmidt and L. Kumar. 1997. Use of Remote Sensing and GIS for sustainable land management. ITC Journal, 3(4):302-315.

Sotomayor, A.I.T. 2002. A Spatial Analysis of Different Forest Cover Types Using GIS and Remote Sensing Techniques: A Case Study in Shivapuri Area, Nepal. M.Sc. dissertation submitted to Forest Science Division, ITC. 